ACTA THERIOLOGICA

Vol. 27, 25: $365-375,1982$

\title{
Demographic Processes in a Forest Roe Deer Population ${ }^{1}$
}

\author{
Bogusław FRUZIŃSKI \& Lesław ŁABUDZKI
}

\begin{abstract}
Fruziński B. \& Łabudzki L., 1982: Demographic processes in a forest roe deer population. Acta theriol., 27, 25: 365-375 [With 4 Tables \& 1 Fig.]

Studies were made from 1975-1980 of the functioning of a population of forest roe deer, Capreolus capreolus (Linnaeus, 1758) in an extensive forest area (about 8,000 ha). The index of potential reproductivity defined by analysis of the embryos of 71 does, was found to be 1.56 emryos per doe over 21 months old and 1.82 emryos in gestating does. Effective population increase was on an average $66.5 \%$ of the whole female part of the population, including yearling females not taking part in reproduction. The estimated index of effective increase was on an average 0.9 fawns per individual capable of reproduction. The natural mortality among adult individuals is due primarily to winters with severe frosts and heavy snowfall. The greatest losses $(33.4 \%$ and $34.8 \%$ of the autumn head of roe deer) were found during the two winters when snow cover persisted for a long time. Mortality is also high among fawns during the first 6 months of life, being on an average $37.6 \%$. Average length of life was found to be 2.9 years, calculated from the life table drawn up on the basis of known mortality among fawns and the age of 250 does, and a survival curve plotted. [Dept. of Game Management, Academy of Agriculture, Wojska Polskiego 71d, 60-625 Poznań, Poland]
\end{abstract}

\section{INTRODUCTION}

Studies on dynamics of population numbers of roe deer living in an extensive wooded area are difficult to carry out, chiefly on account of the animals' hidden way of life, fairly long life cycle and the considerable interchange of individuals in the population.

Dynamics are governed by reproductivity in both its population aspects, i.e. potential and effective, and also by mortality, that is, survival of the different age classes under given habitat conditions. Detailed population parameters are considered as belonging to what is known as the functional aspects of population structure. This is of great importance for hunting practice, for the proper conduct of which it is essential to know the annual population balance, mainly in order to plan correctly the number to be shot, and in particular to achieve optimum results. An attempt at modelling a roe deer population in this direction has been undertaken previously (Bobek et al., 1974; Łomnicki, 1974).

${ }^{1}$ Praca wykonana $w$ ramach problemu MR-II/15 kordynowanego przez Instytut Ekologii Polskiej Akademii Nauk. 
The purpose of the present study was to obtain basic data on the most important population processes in forest roe deer, Capreolus capreolus (Linnaeus, 1758) (reproductivity, mortality, survival) and to define the annual population balance in a given hunting range.

\section{STUDY AREA, METHODS AND MATERIAL}

The studies were carried out at the "Zielonka" Hunting Experimental Centre, cccupying an extensive stretch of forest (about $8,000 \mathrm{ha}$ ). The species composition of the tree stands and quality of biotopes represent the average type of forest hunting range in the Wielkopolska region in the western part of Poland. A detailed description of tree stands and biotopes has been given by Fruziński et al., 1983.

In order to obtain the most accurate data possible, part of the range (Potasze forest district) about 700 ha in extent was chosen, on which studies were concentrated over the period 1975-1980. The character of the tree stands and density of the roe deer population were similar there to other parts of the Centre, but the area was partly isolated from the remainder of the wooded land. From 1978-1980 studies were carried out over the whole Centre, including the part of it (Boduszewo forest district) on which no roe deer had been shot owing to studies being carried out there on the spatial organisation of the population (observations of individually marked animals).

Numbers and population density were determined by organized drives, the technique of which has been described earlier (Pucek et al., 1975). Driving was carried out twice a year (early spring and autumn).

In order to determine the degree of potential reproductivity, analysis was made of the embryos of 71 does shot in February, when macroscopic definition of the sex of the embryos was not difficult in view of advanced embryonic development.

The degree of effective increase was defined on the basis of the ratio of spring numbers of does to fawns found during early autumn driving census. During the spring drives it was possible to divide individuals observed only into male and female, without further division into the fawn class, chiefly on account of the slight differences in size and difficult observation conditions (narrow separation lines, considerable speed of escape, etc.).

Natural mortality was established from the difference in numbers of individuals of different sex during successive drives, always carried out in the same area, with simultaneous known and strictly recorded losses due to the planned shooting. Under forest conditions there are considerable technical difficulties in defining sex and age of individuals which had died during the winter.

\section{RESULTS}

\subsection{Population Numbers}

Population numbers and density during the study period were distinguished by great variability (Table 1), since they were formed under the influence both of shooting, and especially of two snowy winters not typical of the Wielkopolska region, during which tre greatest decrease in population density took place in spring. After the winter of $1976 / 77$ 
density fell to 20.7 individuals $/ 100$ ha, and in spring 1979 to 16.7 individuals/100 ha. Fluctuations in population density in autumn were far smaller (Table 1).

Table 1

Numbers and density of the roe deer population at Zielonka.

\begin{tabular}{|c|c|c|c|c|c|}
\hline $\begin{array}{l}\text { Date } \\
\text { of drive }\end{array}$ & Total & Males & Females & $\begin{array}{l}\text { Fawns } \\
\text { (sex indet.) }\end{array}$ & $\mathrm{N} / 100$ ha \\
\hline \multicolumn{6}{|c|}{ Spring } \\
\hline Apr. 28, 1975 & 170 & 81 & 89 & $x$ & 24.3 \\
\hline May 8,1976 & 176 & 75 & 101 & $x$ & 25.1 \\
\hline Apr. 23,1977 & 145 & 57 & 88 & $x$ & 20.7 \\
\hline Apr. 22,1978 & 159 & 62 & 97 & $x$ & 22.7 \\
\hline May 8,1979 & 117 & 35 & 82 & $x$ & 16.7 \\
\hline \multicolumn{6}{|c|}{ Autumn } \\
\hline Nov. 11,1975 & 218 & 70 & 87 & 61 & 31.1 \\
\hline Nov. 20,1976 & 225 & 53 & 110 & 62 & 32.1 \\
\hline Nov. 12.1977 & 205 & 43 & 95 & 67 & 29.3 \\
\hline Nov. 15,1978 & 198 & 46 & 93 & 59 & 28.3 \\
\hline
\end{tabular}

3.2. Reproductivity

Potential reproductivity index was found to be 1.56 fawns per doe over 21 months old, and 1.82 embryos in gestating does (Table 2).

The fertility of the different age classes is relatively high, does from $5-8$ years old being most productive. The largest percentage of "barren" does is found among the youngest and oldest females (Table 2). Among

Table 2

Potential reproductivity of roe deer based on analysis of embryos.

\begin{tabular}{|c|c|c|c|c|c|c|c|}
\hline \multirow{2}{*}{$\begin{array}{c}\text { Age } \\
\text { of the } \\
\text { females } \\
\text { yrs }\end{array}$} & \multicolumn{2}{|c|}{ No. of females } & \multirow{2}{*}{$\begin{array}{l}\text { No. of } \\
\text { embryos }\end{array}$} & \multicolumn{2}{|c|}{ Avg. per 1 q } & \multirow{2}{*}{$\begin{array}{l}\text { Sex ratio } \\
\text { in embryos }\end{array}$} & \multirow{2}{*}{$\begin{array}{c}\text { Non- } \\
\text { pregnant } \\
\text { females, \% }\end{array}$} \\
\hline & Total & Pregnant & & Total & Pregnant & & \\
\hline $\begin{array}{c}1-2 \\
3-4 \\
5-6 \\
7-8 \\
\text { above } 8\end{array}$ & $\begin{array}{r}14 \\
11 \\
22 \\
18 \\
6\end{array}$ & $\begin{array}{r}10 \\
9 \\
20 \\
17 \\
5\end{array}$ & $\begin{array}{c}14 \\
15 \\
38 \\
34 \\
10\end{array}$ & $\begin{array}{l}1.00 \\
1.36 \\
1.73 \\
1.89 \\
1.67\end{array}$ & $\begin{array}{l}1.40 \\
1.67 \\
1.90 \\
2.00 \\
2.00\end{array}$ & $\begin{array}{l}1: 1.7 \\
1: 1.2 \\
1: 1.2 \\
1: 1.1 \\
1: 1.1\end{array}$ & \begin{tabular}{r|r|}
28.6 \\
18.2 \\
9.1 \\
5.5 \\
16.7
\end{tabular} \\
\hline Total & 71 & 61 & 111 & 1.56 & 1.82 & $1: 1.25$ & 14.0 \\
\hline
\end{tabular}

individuals taking part in reproduction the number of embryos increases with age. Does five years old and older usually have 2 embryos. Fertility is lowest in the youngest females, amongst which, in addition to a considerable percentage of does not participating in reproduction, females with 1 embryo only were most often encountered (about $60 \%$ ). 
The reproductive potential of the female roe deer, calculated under given conditions after Sieviercov's equation (1941):

$$
q=(r+1)^{1 / p \cdot j \cdot s}
$$

was 1.67 , taking into account the following basic data:

$q$ - reproductive potential,

$r-$ number of progeny in litter -1.56 ,

$p-$ period between litters in years -1 ,

$j-$ age at which sexual maturity is reached -1.5 ,

$s-$ sex ratio.

Effective increase exhibits only slight variations in different reproduction seasons (from $0.61-0.76$ ). The average in a population of forest roe deer is $66.5 \%$ in relation to the whole female part of the population during the spring census, including female fawns not taking part in reproduction in the given year (Table 3 ).

Table 3

Yearly balance of roe deer population at Zielonka.

\begin{tabular}{lccccc}
\hline \multicolumn{1}{c}{ Items } & 1975 & 1976 & 1977 & 1978 & Average \\
\hline $\begin{array}{c}\text { Number of population } \\
\text { in spring } \\
\text { in autumn }\end{array}$ & 170 & 176 & 145 & 159 & 162 \\
$\begin{array}{c}\text { Realised productivity in \% of the } \\
\text { female part of populaion }\end{array}$ & 218 & 225 & 205 & 198 & 211 \\
$\begin{array}{l}\text { (yearlings included) } \\
\begin{array}{l}\text { Number of does and fawns shot } \\
\text { Number of population }\end{array}\end{array}$ & 68.5 & 61.4 & 76.0 & 61.0 & 66.5 \\
$\begin{array}{l}\text { in the next spring } \\
\begin{array}{l}\text { Winter losses individuals, n } \\
\text { \% of the autumnal size of }\end{array}\end{array}$ & 176 & 145 & 159 & 117 & 149 \\
$\begin{array}{c}\text { population } \\
\text { Total ratio of the utilization in } \\
\text { \% of the size of population } \\
\text { in spring }\end{array}$ & 4.6 & 33.4 & 8.3 & 34.8 & 20.8 \\
\hline
\end{tabular}

On the basis of the known number of fawns shot during the season and the extent of total winter mortality, the effective increase index was calculated, with a high degree of probability, as on an average about $0.9(0.8-1.0)$ for each female roe deer capable for reproduction. This index was obtained for an intensively used roe deer population, in which the number of animals shot over the 5 -year study period was $21.9 \%$ of the spring population numbers.

In the part of the range which had been completely exempt from shooting for several years, in which 'studies were made, inter alia, on the spatial structure of the population (Boduszewo forest district), and 
the spring density of the population was 26 individuals/100 ha, the effective increase index was on an average for 1977 and 1978 only 0.59 fawns for one female in the population ( 0.63 and 0.56$)$.

In both study areas greatest effective increase vas observed in 1977, with low spring population numbers due to high winter mortality.

\subsection{Mortality}

\subsubsection{Mortality among Adult Animals}

The mortality index among adult animals is formed, inter alia, by the population balance. Maximum natural loss of roe deer was recorded during the winter period and varied from year to year. According to estimated data from areas over the whole Centre $(8,000$ ha) winter mortality was

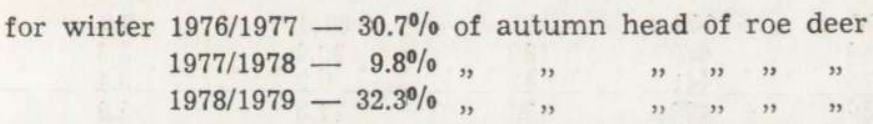

The reliability of the above data is confirmed by accurate observations in a strictly controlled part of the range in which a census was carried out twice a year, in early spring and autumn, in the same experimental areas (Table 3).

The data point to a distinct relation between mortality index and conditions during the winter period, which confirms the generally acknowledged low resistance of roe deer to persistent snow cover and low temperatures in winter.

Considerable losses were caused during the late winter of 1976/1977, when after a long period without snow there was an abundant snowfall persisting up to the end of March. Mortality was very high during the exceptionally snowy and frosty winter of $1978 / 1979$. During the winters with low snowfall, most often occurring in the study region, winter mortality is relative low and does not exceed $10 \%$ of the autumn population numbers.

Summer mortality among adult individuals is minimum and is usually due to sporadic accidents. The slight differences in head of roe deer from the spring and autumn census may be due to a technical error in estimating numbers under difficult forest conditions (Table 1).

\subsubsection{Summer Mortality among Fawns}

Approximate data on mortality among fawns during the first 5-6 months of life were obtained from the strictly controlled study area, 
on the basis of known indices of reproductivity potential and effective increase. Mortality is high among fawns and is on an average for a period of 5 years as much as $37.6 \%$ for the period from May to November (from $33.7-44.6 \%$ ). It is impossible accurately to establish causes of mortality among fawns under forest conditions.

The most complete analysis of mortality phenomena is provided by what is known as life tables (Dasmann, 1964; Caughley, 1977). The life table for the forest roe deer population at Zielonka (Table 4) was prepared on the basis of an analysis of the age of 250 does shot and the known

Table 4

Life table of roe deer (females) at Zielonka.

\begin{tabular}{rrrrrrr}
\hline$x$ & $d x_{p}$ & $l x_{p}$ & \multicolumn{1}{c}{$l x$} & $d x$ & $q x=\frac{d x}{l x} 100$ & $e x=\frac{t}{l x}$ \\
\hline 0 & $146^{1}$ & 396 & 1000 & 370 & 37.0 & 2.9 \\
1 & 75 & 250 & 630 & 189 & 30.0 & 3.3 \\
2 & 16 & 175 & 441 & 41 & 9.2 & 3.4 \\
3 & 28 & 159 & 400 & 70 & 17.5 & 2.8 \\
4 & 32 & 131 & 330 & 81 & 24.5 & 2.3 \\
5 & 29 & 99 & 249 & 73 & 29.3 & 1.8 \\
6 & 36 & 70 & 176 & 90 & 51.1 & 1.4 \\
7 & 12 & 34 & 86 & 31 & 36.0 & 1.3 \\
8 & 14 & 22 & 55 & 35 & 63.6 & 0.8 \\
8 & 8 & 8 & 20 & 20 & 100.0 & 0.5 \\
\hline
\end{tabular}

$x$ - age in years, $d x_{p}$ - number of roe deer shot in age class, $l x_{p}-$ number alive at start of age class (basic data), $l x-$ number alive at start of age class (data concern 1000 individuals), $d x$ - number of dying during the age interval (data concern 1000 individuals), $q x-$ rate of loss, $e_{x}$ - life expectancy for age class.

${ }^{1}$ Including natural mortality of fawns during first six months of life.

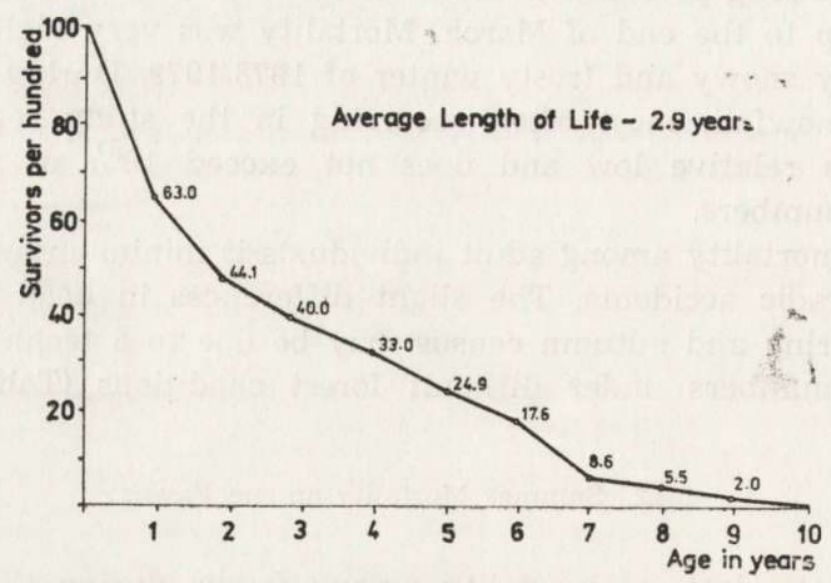

Fig. 1. Survival curve of forest roe deer. 
index of natural mortality among fawns, assuming average winter conditions, when the chief cause of death in the different age classes is shooting.

A survival curve for rde deer was also drawn on the basis of life tables (Fig. 1) and calculation made of the average length of individual life of roe deer, which is 2.9 years. The lighest rate of disappearance was found for individuals up to the age of 2 years. In southern Poland average length of life of roe deer was slightly shorter (2.4 years) (Bobek et al., 1974).

\section{DISCUSSION}

Fluctuations in population density are due to the two most important causes of mortality, natural losses and shooting. Owing to methodological difficulties the third cause, i.e. migration, has not been taken into account in this discussion. Observations of marked individuals permit of stating, however, that it is the young individuals which are involved in migrations, the spatial range of which is limited (Fruziński et al., 1983), and thus in an extensive forest area they take place within the population's living area, not significantly affecting its numbers. There have as yet been no data on the emigration of marked individuals beyond the area of the wooded land studied.

The relatively great variation in the density of the roe deer population during the study period, apart from the obvious seasonal aspect (reproduction), was caused by two winters unusual for the Wielkopolska region - 1976/1977 and 1978/1979. The first of these, despite its otherwise mild course, was distinguished by late snowfall which persisted throughout March and caused losses of $33.4 \%$ of the autumn population numbers. The second snowy and frosty winter caused analogical losses of $34.8 \%$. In both cases shooting was below average level (Table 3 ) and could not have been a significant cause of the drop in population density. The relation between density of the roe deer population at Zielonka and weather conditions and shooting has been analyzed in greater detail by Fruziński et al., (1983). The results of the study fully confirmed the known, although not documented under Polish conditions, high productivity of roe deer populations. In other European populations potential reproductivity exhibits some fluctuation. Under Danish conditions, on the basis of somewhat scanty material (24 roe deer examined in 1970) Strandgaard (1972a) defines it as on an average 1.9 embryos per gestating doe (from 1.7 to 2.1). Swedish roe deer had a higher reproductivity potential, since Borg (1970) found an average of 2.2 embryos for the 362 gestating females he examined. Kurt (1968) gives 
lower values for Switzerland (1.69) and Stubbe \& Passarge (1979) for the German Democratic Republic (1.7), while Hungarian roe deer, according to Szederjei (1967), are distinguished by decidedly the lowest reproductivity potential (1.55). He considers that the value of the reproductivity index depends on habitat conditions.

The average reproductivity potential of roe deer in southern Poland has been estimated by Bobek et al. (1974) as almost identical with that of Zielonka, that is, an average of 1.8 embryos per female. These authors have not stated definitely if the basis for calculation was the presence of corpora lutea or embryos, admitting both these possibilities.

For hunting practice the potential reproductivity index is of greater importance in relation to all female individuals capable of taking part in game management planning. Direct data from studies made it possible

There are not many data on the effect of a doe's age on its fertility. Strandgaard (1972a) makes a fairly general statement that the highest percentage of individuals with only 1 embryo is encountered in does 1.5 years old, taking part in reproduction for the first time. Most often, however, the fertility of the different age classes has been defined on the basis of occurrence of corpora lutea, the number of which, as Borg showed (1970), is usually greater than the number of embryos. The average "ova loss rate" is, in that author's opinion, $9.4 \%$, but he gives no definite causes of this phenomenon.

In the above author's opinion the most fertile does were those from $3-5$ years old (average 2.35 embryos per gestating doe), but differences in relation to other age classes were not significant.

At Zielonka also the lowest number of embryos was encountered in the youngest does. There were, however, no proofs providing evidence of the supposed, according to the commonly held opinion, reduced fertility in individuals in the older age classes (Table 2). The high mortality due to shooting does not usually permit of their reaching the postreproductive age.

Effective increase is high in comparison with that in force in Poland in game management planning. Direct data from studies made it possible to define the degree of effective increase in relation to the whole female part of the population, including yearlings not as yet taking part in reproduction. The percentage of these individuals in the population was defined by means of the drives carried out in early spring in April. Difficult observation conditions in a forest area and the slight differences in size and shape of individuals made it impossible to distinguish without error 10-11 month old does from older ones. The count of effective increase index per doe capable of reproduction, estimated on the strength of basic data, is however sufficiently accurate. 
The number of source data on definite values of effective increase in European roe deer populations is small. In the German Democratic Republic in different regions, from 1968-1970 effective increase was from $0.7-0.82$ per doe in the population (Stubbe \& Passarge, 1979). According to Kurt (1968) effective increase in autumn from 1 doe, depending on the proportion of does in the population, was on an average 0.95 (from 0.51 - to 1.27 ), that is, almost identical with that at Zielonka. Maximum increase (1.27) was observed by this author with the lowest proportion of does in the population $(36-40 \%)$. The amount of effective increase probably depends on population density and with the degree of shooting connected with this. In the roe deer population intensively used for shooting in the experimental part of the range, this increase was clearly higher than the increase found in that part of the range (Boduszewo forest district) in which no roe deer were shot. This would confirm the known ecological rule that populations reproduce more intensively, the greater the use made of them (Severcov, 1941; MacArthur, 1971). This is of great importance in hunting practice.

A far more important factor limiting population numbers are the weather conditions during the winter period, since they are the most important cause of natural loss, regardless of intensity of shooting.

There are few definite study data on the rate and causes of mortality among adult individuals. According to Borg (1970), who analyzed the bodies of 2,827 roe deer from 1948-1969 from different parts of Sweden, the causes of death were: in $58.6 \%$ exhaustion of the organism (chiefly due to starvation), in $10.2 \%$ mechanical injuries (as the result of road accidents, fights, falls from rocks, old shot wounds etc.), on $13.5 \%$ predators and $17.6 \%$ various diseases.

Fairly detailed information based on return reports from 77 marked individuals by Strandgaard (1972b). Causes of losses in $55 \%$ of cases were emigration, in $17 \%$ deaths in the study area due to different causes, including disease, and $14 \%$ road accidents.

In neither of the cases referred to, however, is there any information on the extent of winter losses in definite study seasons, and the numerous cmigration of roe deer at Kalø was certainly due to excessive population density, the fact that the study area was situated in fields (wooded stretches of 175 and 165 ha) and intensive use in neighbouring areas.

In the case of the forest roe deer at Zielonka the most important factor limiting population numbers consisted in weather conditions during the winter period (Table 3). The forest area, which was difficult to penetrate, and the occurrence of wild boar and foxes, which consumed dead animals, made it impossible to define losses in different age classes 
on the basis of the remains of dead animals found. They formed only about $20 \%$ of winter losses.

According to all the sources available summer mortality among fawns is high during the first 6 months of life. At Kalø the average number of fawns in the autumn of different years was $34.3 \%$ (from $18 \%$ to $47 \%$ ) of the spring population numbers (Strandgaard, 1972). The number of fawns per each female capable of reproduction varied from 0.5 to 1.6 fawns (average 1.0), which suggests, with one exception, that mortality among fawns was high. The author gives the large number of foxes, which had previously been greatly reduced, as the cause of high mortality from 1967-1968.

Among the most important reducing factors at Zielonka consideration must be given the great density of wild boar (about 20 individuals/1000 ha of forest) and the occurrence of the fox, and near the numerous groups of buildings for recreational purposes, the activities of dogs and humans.

In southern Poland losses among fawns from May to October were on an average $37.4 \%$ of the number born (Bobek et al., 1979) and were thus identical with those under conditions in the Wielkopolska region $(37.6 \%)$.

The life table for the roe deer population at Zielonka was drawn up solely for females, for which shooting acts distinctly at random in relation to all age classes (Fruziński \& Eabudzki, 1982). Caughley (1977) expresses some reservations in relation to this method of obtaining basic data, since hunters usually shoot the largest individuals or those with the best antlers. At Zielonka the shooting of does is most certainly random in character. In addition, in view of low mortality under the conditions of normal winters, the roe deer population at Zielonka has the distinct characteristics of a population with a stabilized age structure, which makes it possible to apply the given method of collecting and analyzing data.

\section{REFERENCES}

1. Bobek B., Drożdż A., Grodziński W. \& Weiner J., 1974: Studies on productivity of roe deer population in Poland. XI Intern. Congress Game Biol.: 115-123.

2. Borg K., 1970: On mortality and reproduction of roe deer in Sweden during the period 1948-1969. Swedish Widlife, 7: 121-149.

3. Caughley G., 1977: Analysis of vertebrate populations. J. Wiley: 1-232. New York, London.

4. Dasmann R. F., 1964: Wildlife biology. J. Wiley: 1-231. New York, London.

5. Fruziński B., Łabudzki L. \& Wlazełko M., 1983: Habitat, density and spatial structure of the forest roe deer population. Acta theriol., 28.

6. Fruziński B. \& Łabudzki L., 1982: Sex and age structure of forest roe deer population under hunting pressure. Acta theriol., 27: 377-384. 
7. Kurt F., 1968: Das Sozialverhalten des Rehwildes. Mammalia depicta, 4: 1-102. Paul-Parey. Hamburg, Berlin.

8. Łomnicki A., 1975: Modeling and optimalization of roe deer productivity. Polish ecol. Stud., 2: 137-142.

9. Mac Arthur R. \& Connell J., 1971: Biologia populacji. Państw. Wyd. Roln. i Leśne: 1-232. Warszawa.

10. Pucek Z., Bobek B., Łabudzki L., Miłkowski L., Morow K. \& Tomek A., 1975: Estimates of density and number of ungulates. Polish ecol. Stud., 1: 121-135.

11. Sablina T. B., 1955: Kopytnyje Belovežskoj Pušč. Tr. Inst. Morfologii Životnych, 15: 1-191. Moskva.

12. Severcov S. A., 1941: Dinamika naselenija i prisposobitelnaja evolucja životnych. Izd. Akad. Nauk SSRR: 1-232. Moskva, Leningrad.

13. Strandgaard H., 1972a: An investigations of corpora lutea, embryonic development, and time of birth of roe-deer (Capreolus capreolus) in Denmark. Danish Rev. Game Biol., 6: 1-22.

14. Strandgaard H., 1972b: The roe deer (Capreolus capreolus) population at Kalø and the factors regulating its size. Danish Rev. Game Biol., 1: 1-202.

15. Stubbe Ch., \& Passarge H., 1979: Rehwild. VEB Deutscher Landwirtschaftsverlag: 1-431. Berlin.

16. Szederjei A., 1967: Die Folgen der "Uberpopulation" des Rehwildes. Erdö es Faipar, 12: 15-16. Budapest.

Accepted, July 29, 1982.

Bogusław FRUZIŃSKI i Lesław ŁABUDZKI

PROCESY DEMOGRAFICZNE W POPULACJI SARN LESNYCH

\section{Streszczenie}

W latach 1975-1980 na terenie Łowieckiego Ośrodka Doświadczalnego „Zielonka” Akademii Rolniczej w Poznaniu przeprowadzono badania nad funkcjonowaniem populacji sarny w dużym kompleksie leśnym (ok. 8000 ha) uzyskując szereg danych podstawowych dotyczących najważniejszych procesów populacyjnych. Na podstawie analizy embrionów 71 kóz odstrzelonych w lutym określono wskaźnik rozrodezości potencjalnej, który wyniósł 1,56 embrionu na jedną zdolną do rozrodu samicę, przy czym najwyższą płodnością odznaczały się kozy w wieku 5-8 lat (Tabela 2). Wobec wysokiej śmiertelności (średnio 37,6\% urodzonych) koźląt w pierwszych 6 miesiącach życia przyrost zrealizowany kształtował się na poziomie 0,66 na 1 żeńskiego osobnika populacji (Tabela 3), co oznacza około 0,9 na jedną kozę zdolną do rozrodu. Smiertelność osobników dorosłych występuje prawie wyłącznie w okresie zimowym, a jej wysokość jest ściśle uzależniona od długości zalegania pokrywy śnieżnej. Największe straty, rzędu ponad $30 \%$ stanu jesiennego populacji powstają w warunkach długiego zalegania pokrywy śnieżnej (Tabela 3).

$\mathrm{Na}$ podstawie analizy wieku 250 odstrzelonych kóz oraz znajomości wskaźnika śmiertelności koźląt opracowano tabelę życia sarn osobników żeńskich (Tabela 4) oraz sporządzono krzywą przeżywania (Ryc. 1). Srednia długość życia osobniczego sarn jest w warunkach leśnych niska i wynosi 2,9 lat. 